\section{Feet and Fashion}

SIR,-In connexion with your leading article "Feet and Fashion" (21 November, p. 1282), some figures concerning the epidemiology of fashion may be of interest to your readers. During school medical inspection in $1964 \mathrm{I}$ have recorded the footwear of children in infant, junior, and secondary modern schools in Lancashire. The following Table shows the results. The figures are

\begin{tabular}{|c|c|c|c|c|c|c|}
\hline \multirow{2}{*}{$\begin{array}{c}\text { Age } \\
\text { Group }\end{array}$} & \multirow{2}{*}{\multicolumn{2}{|c|}{$\begin{array}{l}\text { Type of } \\
\text { Footwear }\end{array}$}} & \multicolumn{2}{|c|}{ Boys } & \multicolumn{2}{|c|}{ Girls } \\
\hline & & & No. & $\%$ & No. & $\%$ \\
\hline \multirow[t]{2}{*}{$\begin{array}{c}\text { Infants } \\
5-7\end{array}$} & $\begin{array}{l}\text { Straight inner } \\
\text { Pointed } \quad \text {. } \\
\text { Others }\end{array}$ & $\begin{array}{c}\text { rder } \\
\ldots \\
\cdots\end{array}$ & $\begin{array}{r}106 \\
3 \\
25\end{array}$ & $\begin{array}{r}79 \cdot 1 \\
2 \cdot 2\end{array}$ & $\begin{array}{r}114 \\
19 \\
23\end{array}$ & $\begin{array}{l}73 \cdot 0 \\
12 \cdot 1\end{array}$ \\
\hline & Total & .. & 134 & & 156 & \\
\hline \multirow[t]{2}{*}{$\underset{8-10}{\text { Juniors }}$} & $\begin{array}{l}\text { Straight inner } \\
\text { Pointed } \quad \ldots \\
\text { Others } \quad \text {. }\end{array}$ & $\begin{array}{c}\text { rder } \\
\because \because \\
\because\end{array}$ & $\begin{array}{r}108 \\
30 \\
42\end{array}$ & \begin{tabular}{l|}
$60 \cdot 0$ \\
$16 \cdot 6$
\end{tabular} & $\begin{array}{r}107 \\
63 \\
24\end{array}$ & $\begin{array}{l}55 \cdot 1 \\
32 \cdot 4\end{array}$ \\
\hline & Total & .. & 180 & & 194 & \\
\hline \multirow[t]{2}{*}{$\begin{array}{c}\text { Secondary } \\
\text { modern } \\
11-15\end{array}$} & $\begin{array}{l}\text { Straight inner } \\
\text { Pointed } \\
\text { Others }\end{array}$ & $\begin{array}{c}\text { rder } \\
\because \because \\
\end{array}$ & $\begin{array}{r}66 \\
125 \\
58\end{array}$ & \begin{tabular}{|l|}
$26 \cdot 5$ \\
$50 \cdot 2$
\end{tabular} & $\begin{array}{r}14 \\
179 \\
44\end{array}$ & $\begin{array}{r}5.9 \\
75.5\end{array}$ \\
\hline & Total & .. & 249 & & 237 & \\
\hline
\end{tabular}

so eloquent that no comment is necessary. The pointed shoes are becoming commonplace not only in the infant but also in the nursery schools, for which unfortunately I have no figures.-I am, etc.,

$$
\text { Rochdale, Lancs. . BORIS KALCEV. }
$$

\section{Hepatic Amoebiasis}

SIR,-Professor Doxiades (7 November, p. 1197) does a useful service in reminding us of both the importance and the difficulty of diagnosing chronic amoebic infections, even in northern Europe. However, he then generalizes from the statistics of incidence of positive amoebic stools quoted in American papers that infestations of the order of $8.5 \%$ of the population might be found in England, France, and Germany. For this area of London such a figure would be, I think, an overestimate. We have examined by direct microscopy more than 20,000 specimens of faeces for parasites since 1950, and I have notes of only five individuals and one house contact in whom cysts of Entamoeba histolytica were seen-a rate of only $0.03 \%$, of cyst-passers. Trophozoites would not have been expected often since stools were not freshly passed in the laboratory. Our rate could perhaps have been increased by the use of culture techniques and warm faeces, but remains low, although other parasitic cysts were seen more frequently and, in particular, Giardia intestinalis cysts were found in about $1 \%$ of all microscopies.

High incidences have been shown in this country within institutions $(40 \%$ by Belios and Cooper ${ }^{1}$ ) and households ( $75 \%$ by Adams and Seaton ${ }^{2}$ ), but I believe not among the general population of areas having good chlorinated water supplies. Nevertheless if the increase in travel overtakes the rise in world standards of hygiene greater numbers of amoebic infections may be seen here, and I would like to conclude by quoting Dr. Doxiades's conclusion in an earlier paper ${ }^{3}$ that " a negative finding [in the stools] no more exeludes the presence of amoebiasis than the negative result of a sputum test excludes tuberculosis."-I am, etc.,

Public Health Laboratory, MAIR Thomas. London N.9.

\section{REFERENCES}

1 Belios, G. D., and Cooper, W., Brit. med. F., $1953,2,805$.
Adams, A. R. D., and Seaton, D. R., ibid., 1949, Doxiades, Th., ibid., 1962, 1, 1807.

\section{Report on a Patient}

SIR,-An organization calling itself the "Institute of Directors Medical Centre" has recently, with no reference from me, examined and reported on a patient of mine.

Their rather unrelated findings have done nothing to help my patient and can only add to the anxiety that he already has about himself. Furthermore, they have sent a copy of this report to him in which the final paragraph advises him because of his chest condition to call $\mathrm{me}$ in if he gets any heavy chest colds.-I am, etc.,

$$
\begin{aligned}
& \text { Walton-on-Thames, P. B. Schofield. } \\
& \text { Surrey. }
\end{aligned}
$$

\section{Addiction to Dextromoramide}

SIR,-The report of a case of drugdependence to dextromoramide (31 October, p. 1136) prompts us to record two further cases.

Case 1.-A male, aged 56 years, was admitted as a psychiatric emergency, having expressed suicidal threats. He had become dependent on Palfium (dextromoramide) and was taking between 8 and 10 tablets daily. The tablets bad originally been prescribed eight months previously for a severe headache which he developed following intrathecal injection of phenol for the relief of sciatica. Dextromoramide was withdrawn with concurrent administration of chlorpromazine $50 \mathrm{mg}$. three times a day and chlordiazepoxide $10 \mathrm{mg}$. three times a day. Trembling, sweating, exhaustion, and continual craving for the drug developed, reaching a peak during the ensuing 24 to 48 hours. He was subsequently discharged, and when last seen three months later was again taking Palfium.

Case 2.-A male, aged 56 years, was seen in the psychiatric clinic and complained of pains in the arms, legs, and back, feelings of tension, and depression. His "rheumatic" pains had been investigated during the preceding four years in several hospitals with negative results. $\mathrm{He}$ refused admission to the psychiatric department and eventually was treated with E.C.T. without any significant improvement. (His brother had previously been treated with E.C.T. for a typical affective illness with complete recovery.) Subsequently he admitted he had been taking Palfium for the relief of his pain for some three months prior to his referral, gradually increasing his consumption to 60 tablets weekly. He stated he felt terrified lest someone would take him off these tablets and said he couldn't live withou them. He again refused in-patient treatment.

Since its introduction in 1957 dextromoramide has acquired a high reputation as a potent central analgesic which is as effective by mouth as by systemic administration. As a morphine substitute the drug was always suspected of having addictive potential, although in February 1964 the manufacturers were unaware of any case of primary addiction in the United Kingdom (personal communication). The Interdepartmental Committee on Drug Addiction (1960) mention four cases of addiction to dextromoramide, while Matts ${ }^{1}$ found only one case of habituation among 60 patients who were taking the drug.

Temple and Attisso ${ }^{2}$ reviewed the Continental literature relating to 24 cases of Palfium addiction. They concluded that, while true primary addiction was unproved, further information was necessary before firm clinical conclusions could be drawn.

From the recent case reports it would appear that this valuable analgesic drug does possess the capacity for "drug-dependence of morphine type." The prescription of dextromoramide for patients with "chronic pain" due to non-malignant conditions should be guarded, particularly where the pain is atypical or where there is evidence of an underlying abnormal personality.-We are, etc.,

Oldham.

\section{J. JOHNSON.}

G. MILNER.

\section{REFERENCES}

Flavell Matts, S. G., Practitioner, 1962, 188, 524 1961, 69, 537 and Attisso, M. A., Presse méd., World Health Organization,
Org., 1964, No. 273.

\section{Fatal Hyperpyrexia with Antidepressant} Drugs

SiR,-The letter of Dr. B. Stanley and Dr. N. R. Pal (17 October, p. 1011) in which they reported a case of fatal hyperpyrexia with phenelzine (Nardil) and imipramine (Tofranil) prompts me to record a similar reaction with phenelzine, desipramine (Pertofran), and chlorpromazine (Largactil) in which all were taken in normal doses.

At noon on 28 August 1964 a 41-year-old woman was admitted to this hospital with a diagnosis of depression and "hysterical" behaviour. She gradually became comatose and showed signs of sympathetic over-stimulation with dilated pupils, flushed skin, perspiration, hypersalivation, and rigid legs with ankle clonus. Her pulse was regular at 150 , B.P. $130 / 70 \mathrm{~mm}$. $\mathrm{Hg}$, temperature $40^{\circ}$ C. $\left(104^{\circ} \mathrm{F}.\right)$, and her respiration was shallow with increasing cyanosis These signs suggested overdose with antidepressant drugs, and it was confirmed that she had been taking phenelzine, desipramine, and chlorpromazine. She was transferred to a general hospital, where she died at 5 p.m. the same day. Post-mortem examination showed no abnormalities apart from the heart, which was dilated, and the myocardium was generally soft and appeared degenerate. (There had been no clinical evidence of heart disease.) A report from the forensic science laboratory showed that chlorpromazine and desipramine had been found in the tissues, but only in therapeutic amounts. No phenelzine could be demonstrated, but it was suggested that this could still have produced the serious reaction even if it had not been taken for a number of days. The cause of death was given as (I) (a) heart failure ; (b) myocardial degeneration precipitated by (II) combined action of antidepressant drugs.

At the coroner's inquest the patient's husband said that on the day before his wife's death she had felt "drowsy and confused" and returned to bed in the morning after taking chlorpromazine as a hypnotic. Before this she had taken chlorpromazine only in the evening. She had been taking phenelzine regularly in doses of $15 \mathrm{mg}$. thrice daily up until the day before her death. Six weeks previously she had been prescribed desipramine, $50 \mathrm{mg}$. thrice daily, but did not take this regularly and certainly not for 48 hours before her death, because she felt that this did not help her. The amount of tablets left in each bottle showed that there was no evidence of overdosage. 
The coroner recorded a verdict in accordance with medical evidence, gave a warning on the dangers of antidepressant drugs, and urged people to make sure with their doctors how and when they should be used.

-I am, etc.,

Saxondale Hospital, L. W. BowEN

Radcliffe-on-Trent, Nottingham.

\section{Urinary Drainage}

SIR,-Mr. H. Davies and Mr. H. Clansey (5 September, p. 632) describe a urinary drainage apparatus which is both cheap and relatively indestructible, but they make a serious error in designing the in-flow tube to go all the way to the bottom of the bottle. Both in-flow and out-flow tubes should be of the same length, and short, so that there is always an air-gap between the level of the urine and the lower end of the connecting tube. There is real danger in the apparatus as they describe it in that elevation of the bottle can cause the bladder to be filled with stagnant urine and antiseptic solution, and organisms have been shown by several studies to be able to swim upstream, as it were, from the collecting device into the bladder.

It is suggested that about $30 \mathrm{ml}$. of $10 \%$ formalin makes a better antiseptic, as there is a strong vapour given off.-I am, etc., Seattle,
Washington, U.S.A.

\section{Equal Pay for Women Doctors}

SIR,-We have very recently returned from Hong Kong, and while there we were made aware not only of the disparity of women doctors' remuneration but also that of the nursing and teaching professions, who are paid $75 \%$ of the male rate for the job.

Perhaps it would be just as well to consider the existing machinery for any pay increases in the Colony. Unlike the United Kingdom, there are no Whitley Councils, but from time to time a salaries commission is set up which deals with all grades in Government service. The 1959 commission discriminated against junior women medical officers, and all grades of female nursing personnel, teachers, and secretaries employed by the Government. We were given to understand that the next salaries commission will meet in March 1965, but the question of equal pay for equal responsibility, irrespective of sex, is not to be on the agenda, but may be dealt with as a separate issue at some unspecified date.

It is essential that this extremely important principal of parity of pay should be dealt with by the 1965 salaries commission, and the Colonial Office, with a Secretary of State whose party is committed to this policy, should remedy these anomalies at the earliest possible opportunity.

We would point out that "other professional women," to quote Dr. Janet Aitken (21 November, p. 1334), are not in the same position as women doctors. Nurses and teachers are in the majority in their professions, whereas men greatly outnumber women in the medical profession. As a corollary to equal pay, children's allowances should be paid to male personnel employed by the Government in the Colony.-We are, etc.,

\section{Survival of General Practice}

SIR,-I believe

(1) The National Health Service, being a significant and worth-while experiment in the social progress of our generation, requires for its maintenance and development in the field of general practice the willing support of a contented profession, in partnership with a wise and progressive Ministry of Health.

(2) Much of our present difficulty arises from arguing our case from the wrong premise. We are for ever seeking to receive, yet there is little talk or study of what more we could render.

(3) The primary objective in the field of general practice is to provide an increasingly efficient and comprehensive service to the public in the neighbourhood of their homes.

(4) Such a service can only be provided and maintained if the family doctor is able to treat his patients in well-planned and modern premises where he is assisted by an adequate staff structure.

(5) No longer can the present inadequate and dilapidated premises, which have survived from a former age, provide the service that the present generation expects from modern medicine. Neither can the individual practitioner be expected to provide their replacement from his own slender resources or income.

(6) The survival of general practice demands that the family doctor has the time and diagnostic aids to deal adequately with his patient, and for this to be practicable and economic the present individuality of the doctors should be channelled so that they learn to work together, preferably from central group premises.

(7) There must be an adequate and readily understood pay structure. The present concept of a predetermined net average income has brought us to the present impasse, and is clearly unable to finance the organization of efficient practice, let alone offer a living wage or incentive to the average doctor.

(8) At the present juncture, a fearful responsibility rests upon the Review Body, the Ministry of Health, and the British Medical Association, not only to produce an amount but also a method-and to signpost the way ahead for the survival of general practice.-I am, etc.,

Birmingham 30 . J. K. H. MCCullough.

\section{Salaried Service}

SIR,-Let me hasten to add my support to Dr. A. L. Bussey's admirable letter (24 October, p. 1076). The inception of the N.H.S. implied a certain degree of Governmental control which was accepted, albeit unwillingly, by the majority of the profession. It is still possible in present conditions to practise medicine with a reasonable degree of freedom and usually in the area of one's own choosing.

How much more dismal our lives would become if, instead of the present admittedly unsatisfactory state of affairs, we opted for a salaried service and committed ourselves irrevocably to be Government employees. Let no one doubt that direction of the profession would follow. Controls would be laid down on our place of practice, promotion, and even in our day-to-day clinical work. Our future would be determined by a hierarchy of civil servants, medical and lay, on whose benevolence we would depend for our promotion prospects.

Whilst agreeing that our present system allows little incentive to better practice, and that the majority of us are grossly overworked and underpaid, do not let us be tempted by false counsels into accepting a salaried service, many of whose advocates are influenced purely by doctrinaire considerations and who are not concerned with preserving what little independence and freedom we still enjoy at present.-I am, etc.,

Hornchurch, Essex.

D. D. Cowen.

\section{Wasted Medical Potential}

SIR,-I can assure Dr. J. L. Brown (14 November, p. 1269) that there are sons of doctors who wish to do medicine but are denied entry even though they have the necessary attributes in full measure and the necessary qualifications. I too find it shocking that this should be so when many of our hospitals cannot be adequately staffed by doctors of any nationality, and when there is a shortage of general practitioners.

Medical education, which used to be carried out in charitable institutions because there were no other places, is now carried out in institutes of medical technology on clinical material. It seems that we have to wait until more of these institutes of technology are built, staffed, and equipped before we can start to train more doctors. By then the practical situation is likely to have become considerably worse.

All around us are many large groups of hospitals serving the community ${ }^{1}$ in co-operation with general practitioners and the Public Health Service, where the real concern and setting up of medicine can be learnt. Combine general practice, public health, and these hospitals with the teaching of medicine and there would be little difficulty in opening up and producing more good doctors quickly.

Meanwhile other more liberal and more intelligent professions welcome our sons ; the loss is medicine's, not theirs.-I am, etc.,

Harrow, Middlesex. F. Allen Binks.

REFERENCE

1 Binks, F. A., Lancet, 1962, 1, 1083.

\section{Prescription Charges}

SIR,-May I please " light a small candle, instead of cursing the darkness," on the lot of the general practitioner? A darkness to become darker it would seem with the removal of the prescription charge. That is to ask the Minister to restore repeat prescriptions by an easier method than those described in the handbook for general medical practitioners.

What I have in mind is something after the fashion of private prescription pads issued by some drug firms. In addition to allowing the doctor to repeat the prescription by one stroke of the pen, the tear-off portion gives printed directions to the patient.

With the modern drugs stemming more from hospital practice, there is a need more than ever for this and for some relief for the family doctor and his "staff."-I am, etc.,

Blackpool, Lanco.

ARCHIs MUTr. 